\begin{tabular}{|l|l|l||}
\hline \multicolumn{2}{|c|}{ PublisherInfo } \\
\hline \hline PublisherName & $:$ & BioMed Central \\
\hline \hline PublisherLocation & $:$ & London \\
\hline \hline PublisherImprintName & $:$ & BioMed Central \\
\hline \hline
\end{tabular}

\title{
Crenarchaeon genome
}

\begin{tabular}{|l|l|l||}
\hline \multicolumn{2}{|c||}{ ArticleInfo } \\
\hline \hline ArticleID & $:$ & 4132 \\
\hline \hline ArticleDOI & $:$ & $10.1186 /$ gb-spotlight-20010628-01 \\
\hline \hline ArticleCitationID & $:$ & spotlight-20010628-01 \\
\hline \hline ArticleSequenceNumber & $:$ & 203 \\
\hline \hline ArticleCategory & $:$ & Research news \\
\hline \hline ArticleFirstPage & $:$ & 1 \\
\hline \hline ArticleLastPage & $:$ & 2 \\
\hline \hline & $:$ & RegistrationDate : 2001-06-28 \\
ArticleHistory & $:$ & OnlineDate $\quad$ 2001-06-28 \\
\hline \hline ArticleCopyright & $:$ & BioMed Central Ltd2001 \\
\hline \hline ArticleGrants & $:$ & \\
\hline \hline ArticleContext & $:$ & 130592211 \\
\hline \hline
\end{tabular}




\section{Jonathan B Weitzman}

Email: jonathanweitzman@hotmail.com

Sulfolobus solfataricus is a model organism for the study of the crenarchaeal branch of the Archaea. It is remarkable for its optimal growth conditions: $80 \mathrm{oC}$ and $\mathrm{pH} 2-4$, metabolizing sulfur. In the July 3 Proceedings of the National Academy of Sciences, She et al. report completion of the genome sequence of S. solfataricus by a Canadian-European collaborative project(Proc Natl Acad Sci USA 2001, 98:7835-7840). The genome is almost 3 megabases long on a single chromosome and encodes 2977 proteins, many of which are Sulfolobus- and/or archaea-specific. The largest family of genes are those involved in fatty acid biosynthesis. She et al. report extensive analysis of genes involved in metabolic pathways, protein transport, DNA replication and the cell cycle, DNA repair, transcription and translation. One interesting result is the use of ferredoxin (rather than NADH) as the primary metabolic electron carrier. Differences in the machineries of the cell cycle; DNA replication and translation underlie the distinction between crenarchaea and euryarchaea.

\section{References}

1. The Sulfolobus solfataricus P2 genome project

2. Proceedings of the National Academy of Sciences, [http://www.pnas.org]

3. Sulfolobus solfataricus $\mathrm{P} 2$ complete genome sequencing project, [http://www-archbac.u-psud.fr/ projects/sulfolobus] 